\title{
Analisis Rasio Likuiditas, Solvabilitas, Aktivitas Dan Profitabilitas Dalam Menilai Kinerja Keuangan Perusahaan
}

\author{
Tarsija $^{1}$, Pandaya ${ }^{2}$ \\ ${ }^{1}$ STIE Muhammadiyah Jakarta, tarsija@stiemj.ac.id \\ ${ }^{2}$ STIE Muhammadiyah Jakarta, pandaya@ sismadigroup.com
}

\begin{abstract}
ABSTRAK
Penelitian ini merupakan studi kasus dengan obyek penelitian yaitu PT. Pilot Pen Indonesia. Teknik pengumpulan dilakukan dengan dokumentasi terhadap laporan keuangan meluputi neraca, laporan laba rugi dan harga pokok penjualan. Dalam mengukur kinerja keuangan perusahaan, teknik analisis data yaitu analisis rasio keuangan meliputi 1). Likuiditas (Current Ratio, Quick Ratio, dan Cash Ratio) 2). Solvabilitas (Debt to Assets Ratio dan Debt to Equity Ratio), (3). Aktivitas (Fixed Assets Turnover, Inventory Turnover) dan (4). Profitabilitas (Gross Profit Margin, Net Profit Margin dan Return on Equity) tahun 2012-2016 dengan membandingkan rasio standar industri. Berdasarkan hasil penelitian dan analisa menunjukan bahwa 1). Kinerja Keuangan PT. Pilot Pen Indonesia selama 2012-2016 ditinjau dari likuiditas menunjukkan bahwa hasil ini dengan masing-masing indikator tersebut dalam kategori cukup baik (likuid). 2). Hasil penelitian kinerja keuangan menunjukan masing-masing indikator tersebut dalam kategori cukup baik (solvabel. Selanjutnya Kinerja Keuangan ditinjau dari Aktivitas pada Fixed Turnover dan Inventory Turnover tahun 2012-2016 hasil ini menunjukan fluktuasi dari tahun ke tahun dan dikategorikan kurang baik (tidak efesien). Kinerja Keuangan ditinjau dari Profitabilitas pada Gross Profit Margin, Net Profit Margin dan Return on Equity tahun 2012-2016 Hasil ini menunjukan fluktuasi dari tahun ke tahun dan dikategorikan kurang baik (tidak efesien).

Kata kunci : analisis rasio, kinerja keuangan, rasio likuiditas, rasio solvabilitas, rasio aktivitas, rasio profitabilitas
\end{abstract}

\begin{abstract}
This research is a case study with research objects namely PT. Indonesian Pilot Pen. The collection technique is done by documenting the financial statements covering the balance sheet, income statement and cost of goods sold. In measuring the company's financial performance, data analysis techniques namely financial ratio analysis include 1). Liquidity (Current Ratio, Quick Ratio, and Cash Ratio) 2). Solvency (Debt to Assets Ratio and Debt to Equity Ratio), (3). Activities (Fixed Assets Turnover, Inventory Turnover) and (4). Profitability (Gross Profit Margin, Net Profit Margin and Return on Equity) in 2012-2016 by comparing the ratio of industry standards.

Based on the results of research and analysis shows that 1). Financial Performance of PT. Indonesian Pilot Pen during 2012-2016 in terms of liquidity shows that this result with each of the indicators in the category is quite good (liquid). 2). The results of the financial performance research show that each of these indicators is in a fairly good category (solvable. Furthermore, Financial Performance in terms of Activities in the Fixed Turnover and Inventory Turnover in 2012-2016 these results indicate fluctuations from year to year and are categorized as not good (inefficient). Financial Performance in terms of Profitability in Gross Profit Margin, Net Profit Margin and Return on Equity in 2012-2016 These results show fluctuations from year to year and are categorized as not good (inefficient).
\end{abstract}

Keywords: ratio analysis, financial performance, liquidity ratios, solvency ratios, activity ratios, profitability ratios 


\section{JURNAL AKUNTANSI, Vol. 8, No. 1, April (2019)}

\section{PENDAHULUAN}

Era Pasar Bebas Asia Tenggara atau Masyarakat Ekonomi Asean (MEA) yang resmi diberlakukan pada akhir 2015, merupakan sebuah integrasi ekonomi kawasan di Asia Tenggara yang bertujuan meningkatkan daya saing di ASEAN dan perdagangan intrakawasan Asia Tenggara. Namun pemberlakuan MEA akan menjadi tantangan tersendiri bagi perusahaan dalam hal ini khususnya perusahaan manufaktur. Secara konseptual, MEA dapat memberi peluang terbukanya pasar produk Indonesia di kawasan ASEAN, akan tetapi di sisi lain jika tidak diwaspadai akan berdampak pada banyaknya produk-produk negara ASEAN lainnya di Indonesia, hal ini akan mengancam keberlangsungan industri manufaktur nasional.

Seiring berkembangnya teknologi, pertumbuhan industri manufaktur yang semakin cepat, mendorong eksistensi perusahaan baik dalam skala besar maupun skala kecil akan berdampak pada tingginya persaingan. Industri manufaktur saat ini dalam perkembangannya masih terdapat beberapa terkendala yang salah satunya yaitu kesulitan dalam hal pemasaran/penjualan, bahan baku. Kesulitan tersebut dikarenakan konsumsi masyarakat tidak signifikan serta banyaknya industri yang saling bersaing untuk memperoleh loyalitas pelanggan. Dalam menghadapi kompetisi tersebut, perusahaan dituntut untuk memiliki kelangsungan usaha (going concern). Kelangsungan hidup perusahaan tersebut tidak terlepas dari faktor-faktor yang mempengaruhinya, diantaranya dapat berupa faktor keuangan maupun non-keuangan yang bersangkutan.

Salah satu tujuan utama didirikannya perusahaan adalah untuk memperoleh keuntungan (profit) secara maksimal dan meningkatkan nilai tambah bagi perusahaan. Namun demikian, berhasil tidaknya dalam mencari keuntungan serta mempertahankan perusahaan, hal ini tergantung pada hasil kinerja manajemen keuangan perusahaan itu sendiri, dimana hasil kinerja manajemen keuangan merupakan dasar dalam pengambilan keputusan baik itu bagi pihak internal maupun eksternal. Untuk itu, pihak manajemen keuangan dituntut melakukan perencanaan dan pengendalian yang efektif dan efisien.

Umumnya, alat yang digunakan mengukur kinerja keuangan adalah laporan keuangan, dimana laporan keuangan merupakan informasi yang menunjukkan posisi keuangan, kinerja, serta perubahan posisi keuangan perusahaan dalam suatu periode tertentu. Laporan keuangan sangat berguna bagi stakeholder, baik dari sisi internal maupun eksternal. Dari sisi internal laporan keuangan menjadi dasar manajemen perusahaan untuk mengevaluasi kebijakankebijakan perusahaan. Sedangkan eksternal khususnya investor sebagai panduan pengambilan keputusan menanamkan atau mempertahankan dananya di perusahaan tersebut.

Salah satu alat yang digunakan untuk menganalisa laporan keuangan adalah rasio keuangan. Rasio keuangan merupakan perbandingan antara dua atau kelompok data laporan keuangan dalam suatu periode tertentu, data tersebut bisa antar data dari neraca dan data laporan rugi laba sehingga memberi gambaran mengenai kelemahan dan kemampuan keuangan suatu perusahaan dari tahun ke tahun. Analisis rasio ini akan sangat membantu dalam menilai prestasi manajemen keuangan di masa lalu dan prospeknya di masa yang akan datang. Dengan kata lain analisis rasio keuangan merupakan suatu metode analisa yang membandingkan pos laporan keuangan dengan pos lainnya untuk menilai kinerja perusahaan. Tujuan dari rasio keuangan adalah membantu manajer dalam memahami apa yang perlu dilakukan perusahaan sehubungan dengan informasi yang berasal dari keuangan yang sifatnya terbatas.

Hasil dari perbandingan tersebut dapat digunakan untuk mengetahui tingkat rasio likuiditas, solvabilitas, aktivitas dan profitabilitas yang dapat menggambarkan kondisi keuangan dan kinerja perusahaan. Rasio likuiditas merupakan rasio yang menyatakan kemampuan perusahaan untuk memenuhi kewajibannya dalam jangka pendek, rasio solvabilitas (leverage), menunjukkan kemampuan perusahaan dalam memenuhi kewajiban jangka panjang, rasio aktivitas menyatakan kemampuan perusahaan dalam memanfaatkan harta yang dimikinya dan rasio profitabilitas menunjukkan kemampuan dari perusahaan dalam menghasilkan keuntungan. 


\section{JURNAL AKUNTANSI, Vol. 8, No. 1, April (2019)}

Berdasarkan uraian di atas maka penulis ingin meneliti mengena analisis rasio likuiditas, solvabilitas, aktivitas dan profitabilitas dalam menilai kinerja keuangan perusahaan pada pt. pilot pen indonesia periode $2012-2016$.

\section{KAJIAN LITERATUR \\ Pengertian Rasio Keuangan}

Menurut Kasmir (2014:104) rasio keuangan adalah: "Rasio keuangan merupakan kegiatan membandingkan angka-angka yang ada di dalam laporan keuangan. Perbandingan dapat dilakukan antara satu komponen dengan komponen dalam satu laporan keuangan atau antar komponen yang ada di antara laporan keuangan. Kemudian angka yang diperbandingkan dapat berupa angka-angka dalam satu periode maupun beberapa periode."

\section{Jenis-Jenis Rasio Keuangan}

Jenis rasio keuangan yang sering digunakan untuk menilai kondisi keuangan dan kinerja perusahaan, yaitu:

\section{a. Rasio Likuiditas (Liquidity Ratio)}

Menurut Kasmir (2014:145) rasio likuiditas atau sering disebut juga dengan nama rasio modal kerja merupakan rasio yang digunakan untuk mengukur seberapa likuidnya suatu perusahaan atau rasio likuiditas berguna untuk mengetahui kemampuan perusahaan dalam membiayai dan memenuhi kewajiban/utang pada saat ditagih atau jatuh tempo. Rasio Likuiditas yang digunakan dalam penelitian ini terdiri atas :

\section{1). Rasio Lancar (Current Ratio)}

Menurut Kasmir (2014:134) adalah "Rasio lancar (current ratio) merupakan rasio untuk mengukur kemampuan perusahaan dalam membayar kewajiban jangka pendek atau utang yang segera jatuh tempo pada saat ditagih secara keseluruhan".

Adapun perhitungan/rumus yang digunakan untuk mencari rasio lancar (current ratio) adalah sebagai berikut :

$$
\text { Rasio Lancar }=\frac{\text { Aset Lancar }}{\text { Kewajiban Lancar }}
$$

\section{2). Rasio Cepat (Quick Ratio) atau Acid test Ratio}

Menurut Kasmir (2013:137) rasio cepat (quick ratio) merupakan rasio uji cepat yang menunjukkan kemampuan perusahaan membayar kewajiban jangka pendek dengan aktiva lancar tanpa memperhitungkan nilai persediaan (inventory). Artinya mengabaikan nilai persediaan dengan cara dikurangi dari total aktiva lancar. Hal ini dilakukan karena persediaan dianggap memerlukan waktu relatif lebih lama untuk diuangkan, apabila perusahaan membutuhkan dana cepat untuk membayar kewajibannya dibandingkan dengan aktiva lancar lainnya.

Adapun perhitungan/rumus yang digunakan untuk mencari rasio cepat (quick ratio) adalah sebagai berikut :

\section{3). Rasio Kas (Cash Ratio)}

$$
\text { Quick Ratio }=\frac{\text { Aktiva Lancar }- \text { Persediaan }}{\text { Kewajiban } \text { Lancar }}
$$

Menurut Kasmir (2014:134) rasio kas merupakan alat yang digunakan untuk mengukur seberapa besar uang kas yang tersedia untuk membayar utang.

Dari hasil pengukuran rasio kas apabila rasio semakin tinggi maka akan semakin baik. Adapun perhitungan/rumus yang digunakan untuk mencari nilai rasio kas (cash ratio) adalah sebagai berikut :

$$
\text { Rasio Kas }=\frac{\text { Kas dan Setara Kas }}{\text { Kewajiban Lancar }}
$$

\section{b. Rasio Solvabilitas (Leverage Ratio)}




\section{JURNAL AKUNTANSI, Vol. 8, No. 1, April (2019)}

Menurut Kasmir (2014:150) rasio solvabilitas merupakan rasio yang digunakan untuk mengukur sejauh mana aktivitas perusahaan dibiayai dengan hutang. Jenis rasio solvabilitas yang digunakan dalam penelitian ini yaitu :

1). Rasio Hutang Terhadap Total Aktiva (Debt to Asset Ratio)

Menurut Kasmir (2014:156) Debt to Asset Ratio merupakan rasio utang yang digunakan untuk mengukur perbandingan antara total utang dengan total aktiva dengan kata lain, seberapa besar utang perusahaan berpengaruh terhadap pengelolaan aktiva. Adapun untuk perhitungan/rumus debt to asset ratio adalah :

\section{2). Rasio Hutang Terhadap Modal (Debt to Equity Ratio)}

$$
\text { Debt to Asset Ratio }=\frac{\text { Total Utang }}{\text { Total Aktiva }} \times 100 \%
$$

Menurut Kasmir (2014:157) debt to equity ratio merupakan rasio yang digunakan untuk menilai utang dengan ekuitas. Rasio ini dicari dengan membandingkan antara seluruh utang, termasuk utang lancar dengan keseluruhan ekuitas. Adapun untuk perhitungan/rumus debt to equity ratio adalah :

$$
\text { Rasio Utang Terhadap Modal }=\frac{\text { Total Utang }}{\text { Total Modal }}
$$

\section{c. Rasio Aktivitas (Activity Ratio)}

Menurut Kasmir (2014:172) Rasio Aktivitas merupakan rasio yang digunakan untuk mengukur efektivitas perusahaan dalam menggunakan aktiva yang dimilikinya. Jenis rasio aktivitas yang digunakan dalam penelitian ini adalah :

1). Perputaran Aset Tetap (Fixed Assets Turnover)

Menurut Kasmir (2014:176) fixed asset turnover merupakan rasio yang digunakan untuk mengukur berapa kali dana yang ditanamkan dalam aktiva tetap berputar satu periode.Adapun perhitungan/rumus untuk fixed asset turnover adalah:

\section{2). Rasio Perputaran Persediaan (Inventory Turnover)}

$$
\text { Perputaran Aset Tetap }=\frac{\text { Penjualan }}{\text { Total Aktiva Tetap }}
$$

Menurut Kasmir (2014:176) inventory turnover merupakan rasio yang digunakan untuk mengukur berapa kali dana yang ditanamkan dalam persediaan berputar satu periode. Adapun perhitungan/rumus untuk inventory turnover adalah:

$$
\text { Perputaran Persediaan }=\frac{\text { Harga Pokok Penjualan }}{\text { Rata }- \text { Rata Persediaan }}
$$

\section{d. Rasio Profitabilitas (Profitability Ratio)}

Rasio Profitabilitas, merupakan rasio yang mengukur kemampuan perusahaan dalam menghasilkan keuntungan pada tingkat penjualan, aset, dan modal saham yang tertentu. (Hanafi dan Halim, 2014:79). Jenis-jenis rasio profitabilitas yang digunakan dalam penelitian ini yaitu :

\section{1). Margin Laba Kotor (Gross Profit Margin)}

Menurut Kasmir (2014:196) merupakan salah satu rasio yang digunakan untuk mengukur margin laba atas penjualan. Margin laba kotor menunjukan laba yang relatif terhadap perusahaan, dengan cara penjualan bersih dikurangi harga pokok penjualan. Rasio ini merupakan cara untuk menetapkan harga pokok penjualan.Adapun perhitungan/rumus yang digunakan untuk mencari gross profit margin yaitu :

$$
\text { Margin Laba Kotor }=\frac{\text { Penjualan Bersih }- \text { Harga Pokok Penjualan }}{\text { Penjualan }}
$$




\section{JURNAL AKUNTANSI, Vol. 8, No. 1, April (2019)}

\section{2). Rasio Margin Laba Bersih (Net Profit Margin Ratio)}

Menurut Hery (2017:198) Net Profit Margin merupakan rasio yang digunakan untuk mengukur besarnya presentase laba bersih atas penjualan. Adapun perhitungan net profit margin dapat diselesaikan dengan rumus:

$$
\text { Net Profit Margin }=\frac{\text { Laba Bersih }}{\text { Penjualan }}
$$

\section{3). Hasil Pengembalian Equitas (Return on Equity)}

Menurut Kasmir (2014:196) Return on Equity merupakan rasio atau rentabilitas modal sendiri merupakan rasio untuk mengukur laba bersih sesudah pajak dengan modal sendiri. Rasio ini menunjukkan efisiensi penggunaan modal sendiri. Semakin tinggi rasio ini semakin baik keadaan perusahaan, artinya posisi pemilik perusahaan semakin kuat. Standar rata-rata industri untuk ROE adalah $40 \%$. Untuk mencari nilai Return on Equity menggunakan rumus :

$$
\text { Return on Equity }=\frac{\text { Laba Bersih }}{\text { Modal Sendiri }}
$$

\section{Pengertian Kinerja Keuangan}

Kinerja keuangan perusahaan merupakan prestasi yang dicapai oleh perusahaan pada saat tertentu dengan menggunakan perhitungan berdasarkan tolok ukur analisis rasio yang didasarkan pada laporan keuangan.

\section{METODE PENELITIAN}

Dalam melakukan analisis data dan pembahasan untuk menilai kinerja keuangan PT. Pilot Pen Indonesia periode 2012-2016, penulis menggunakan 4 (empat) rasio keuangan terdiri dari Likuiditas (Current Ratio, Quick Ratio dan Cash Ratio), Solvabilitas (Debt to Asset Ratio dan Debt to Equity Ratio), Aktivitas (Fixed Asstes Turnovern dan Inventory Turnover), Profitabilitas (Net Profit Margin, Gross Profit Margin, dan Return on Equity) yang mengacu pada laporan keuangan sebagai dasar perhitungan, yang terdiri dari neraca dan laporan rugi/laba dan harga pokok penjualan selama periode 2012-2016.

\section{PEMBAHASAN}

\section{Perhitungan Rasio Likuiditas}

Rasio likuiditas adalah suatu alat pengukur kemampuan dan kekuatan sesungguhnya dari perusahaan untuk memenuhi atau membayar hutang yang harus dibayar tepat pada waktunya.

\section{a. Rasio Lancar (Current Ratio)}

Current Ratio menunjukan hubungan antara aktiva lancar dengan kewajiban lancar, dimana rasio ini digunakan untuk mengukur kemampuan perusahaan dalam memenuhi kewajiban jangka pendek yang segera jatuh tempo pada saat ditagih secara keseluruhan. Tabel 4.1 merupakan hasil perhitungan Current Ratio PT. Pilot Pen Indonesia periode 2012-2016. 
Tabel 4.1

Perhitungan Current Ratio PT. Pilot Pen Indonesia

Tahun 2012 - 2016 (dalam rupiah)

\begin{tabular}{|c|c|c|c|}
\hline Tahun & Aktiva Lancar & $\begin{array}{c}\text { Kewajiban } \\
\text { Lancar }\end{array}$ & $\begin{array}{c}\text { Current } \\
\text { Ratio }\end{array}$ \\
\hline 2012 & 65.519 .035 .458 & 6.249 .374 .117 & $\begin{array}{c}10,48 \\
\text { kali }\end{array}$ \\
\hline 2013 & 71.992 .194 .724 & 13.474 .061 .879 & $5,34 \mathrm{kali}$ \\
\hline 2014 & 47.902 .238 .539 & 19.030 .822 .852 & $2,52 \mathrm{kali}$ \\
\hline 2015 & 45.321 .745 .926 & 22.478 .479 .256 & $2,02 \mathrm{kali}$ \\
\hline 2016 & 58.419 .021 .009 & 27.799 .739 .309 & $2,10 \mathrm{kali}$ \\
\hline \multicolumn{3}{|c|}{ Rata-Rata Current Ratio } & $\mathbf{4 , 4 9}$ kali \\
\hline
\end{tabular}

Sumber : PT. Pilot Pen Indonesia 2012-2016 (diolah)

Apabila digambarkan dalam bentuk grafik, maka nilai Current Ratio PT. Pilot Pen Indonesia periode 2012-2016 :

\section{Grafik 4.1}

Current Ratio PT. Pilot Pen Indonesia Tahun 2012-2016

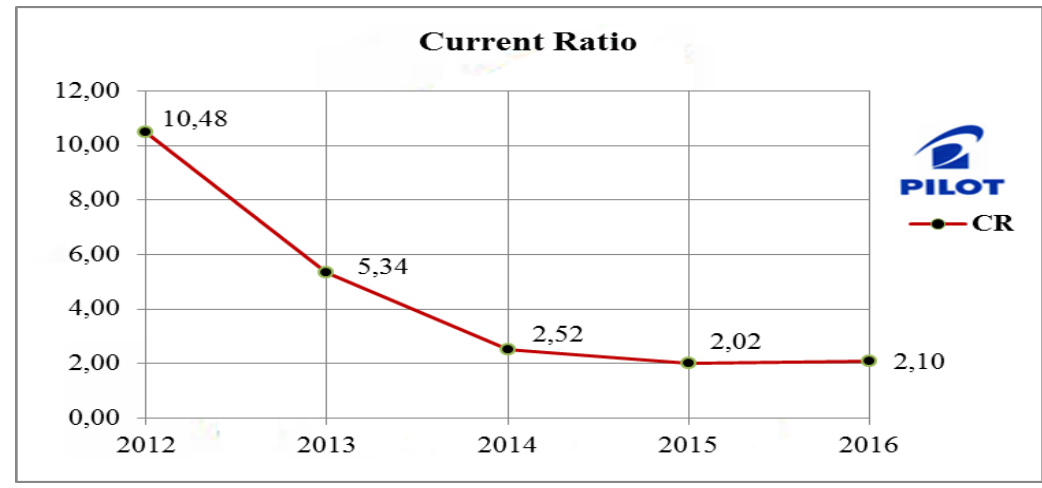

Berdasarkan grafik 4.1. Current Ratio PT. Pilot Pen Indonesia pada tahun 20122016, cenderung mengalami penurunan setiap tahunnya. Dimana nilai rasio tertinggi pada tahun 2012 sebesar 10,48 kali dan terendah terjadi pada tahun 2015 sebesar 2,02 kali. Meskipun Current Ratio terendah pada tahun 2015, kondisi ini menunjukan bahwa perusahaan masih mampu memenuhi kewajiban lancarnya tepat pada waktunya dengan aktiva lancar yang dimiliki perusahaan karena besaran aktiva lancar lebih besar jika dibandingkan dengan kewajiban lancarnya.

Dengan demikian secara keseluruhan dapat diketahui bahwa selama periode 2012-2016 diperoleh rata-rata Current Ratio yang dihasilkan PT. Pilot Pen Indonesia sebesar 4,49 kali artinya hal ini bisa interprestasikan bahwa untuk satu rupiah kewajiban lancar dapat dijamin dengan 4,49 rupiah aktiva lancar dalam setahun.

\section{b. Rasio Sangat Lancar (Quick Ratio)}

Quick Ratio merupakan rasio uji cepat yang menunjukan kemampuan perusahaan membayar kewajiban jangka pendek dengan aktiva lancar tanpa memperhitungkan nilai persediaan. Quick Ratio merupakan perbandingan antara aktiva lancar dikurangi persediaan dengan kewajiban lancar. Tabel 4.2 merupakan hasil perhitungan Quick Ratio PT. Pilot Pen Indonesia periode 2012-2016. 


\section{Tabel 4.2}

Perhitungan Quick Ratio PT. Pilot Pen Indonesia

Tahun 2012 - 2016 (dalam rupiah)

\begin{tabular}{|c|c|c|c|c|}
\hline $\begin{array}{c}\text { Tah } \\
\text { un }\end{array}$ & $\begin{array}{l}\text { Aktiva } \\
\text { Lancar }\end{array}$ & Persediaan & $\begin{array}{c}\text { Kewajiban } \\
\text { Lancar }\end{array}$ & $\begin{array}{c}\text { Qui } \\
\text { ck } \\
\text { Rati } \\
\text { o }\end{array}$ \\
\hline 2012 & $\begin{array}{r}65.519 .035 \\
458 \\
\end{array}$ & $\begin{array}{r}15.598 .036 . \\
924\end{array}$ & $\begin{array}{r}6.249 .374 .1 \\
17\end{array}$ & 7,99 \\
\hline 2013 & $\begin{array}{r}71.992 .194 . \\
724 \\
\end{array}$ & $\begin{array}{r}11.837 .114 . \\
255 \\
\end{array}$ & $\begin{array}{r}13.474 .061 . \\
879 \\
\end{array}$ & 4,46 \\
\hline 2014 & $\begin{array}{r}47.903 .238 . \\
539\end{array}$ & $\begin{array}{r}10.827 .299 \\
727\end{array}$ & $\begin{array}{r}19.030 .822 . \\
852\end{array}$ & 1,95 \\
\hline 2015 & $\begin{array}{r}45.321 .745 . \\
926 \\
\end{array}$ & $\begin{array}{r}22.986 .581 . \\
478 \\
\end{array}$ & $\begin{array}{r}22.478 .479 . \\
256 \\
\end{array}$ & 0,99 \\
\hline 2016 & $\begin{array}{r}58.419 .021 . \\
009 \\
\end{array}$ & $\begin{array}{r}23.838 .747 . \\
566 \\
\end{array}$ & $\begin{array}{r}27.799 .739 . \\
309 \\
\end{array}$ & 1,24 \\
\hline \multicolumn{3}{|c|}{ Rata-Rata Quick Ratio } & & $\mathbf{3 , 3 3}$ \\
\hline
\end{tabular}

Sumber : PT. Pilot Pen Indonesia (diolah)

Apabila digambarkan dalam bentuk grafik, maka nilai Quick Ratio PT. Pilot Pen Indonesia periode 2012-2016:

\section{Grafik 4.2}

Quick Ratio PT. Pilot Pen Indonesia Tahun 2012-2016

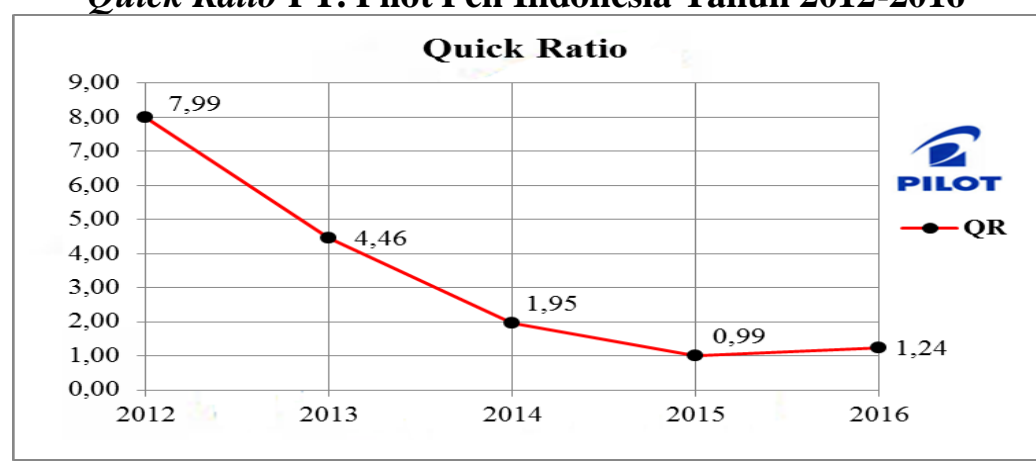

Berdasarkan grafik 4.2. Quick Ratio yang dihasilkan PT. Pilot Pen Indonesia selama tahun 2012-2016 berfluktiasi, dimana besarnya nilai rasio tertinggi terjadi pada tahun 2012 sebesar 7,99 kali dan terendah terjadi pada tahun 2015 sebesar 0,99 kali. Meskipun nilai Quick Ratio terendah pada tahun 2015, kondisi ini menunjukan bahwa perusahaan masih mampu memenuhi kewajiban lancarnya tepat pada waktunya dengan aktiva lancar yang dimiliki perusahaan, hal tersebut dapat terlihat besaran aktiva lancar lebih besar jika dibandingkan dengan nilai persediaan.

Dengan demikian secara keseluruhan dapat diketahui bahwa selama periode 20122016 diperoleh rata-rata Quick Ratio yang dihasilkan PT. Pilot Pen Indonesia sebesar 3,33 kali artinya hal ini bisa interprestasikan bahwa untuk satu rupiah kewajiban lancar dapat dijamin dengan 3,33 rupiah aktiva lancar tanpa memperhitungkan nilai persediaaan dalam setahun.

\section{c. Rasio Kas (Cash Ratio)}

Cash Ratio merupakan rasio yang digunakan untuk mengukur kemampuan membayar kewajiban jangka pendeknya dengan kas dan setara kas. Cash Ratio merupakan 


\section{JURNAL AKUNTANSI, Vol. 8, No. 1, April (2019)}

perbandingan antara kas dan setara kas dengan kewajiban lancar. Tabel 4.3 merupakan hasil perhitungan Cash Ratio PT. Pilot Pen Indonesia periode 2012-2016.

Tabel 4.3

Perhitungan Cash Ratio PT. Pilot Pen Indonesia Tahun 2012 - 2016 (dalam rupiah)

\begin{tabular}{|c|c|c|c|}
\hline Tahun & $\begin{array}{c}\text { Kas \& Setara } \\
\text { Kas }\end{array}$ & $\begin{array}{c}\text { Kewajiban } \\
\text { Lancar }\end{array}$ & $\begin{array}{c}\text { Cash } \\
\text { Ratio }\end{array}$ \\
\hline 2012 & 42.015 .684 .044 & 6.249 .374 .117 & $672 \%$ \\
\hline 2013 & 49.840 .722 .325 & 13.474 .061 .879 & $370 \%$ \\
\hline 2014 & 20.462 .277 .648 & 19.030 .822 .852 & $108 \%$ \\
\hline 2015 & 8.538 .921 .890 & 22.478 .479 .256 & $38 \%$ \\
\hline 2016 & 15.702 .183 .220 & 27.799 .739 .309 & $56 \%$ \\
\hline \multicolumn{3}{|c|}{ Rata-Rata Cash Ratio } & $\mathbf{2 4 9 \%}$ \\
\hline
\end{tabular}

Sumber : PT. Pilot Pen Indonesia (diolah)

Apabila digambarkan dalam bentuk grafik, maka nilai Cash Ratio PT. Pilot Pen Indonesia periode 2012-2016 :

\section{Grafik 4.3}

Cash Ratio PT. Pilot Pen Indonesia Tahun 2012-2016

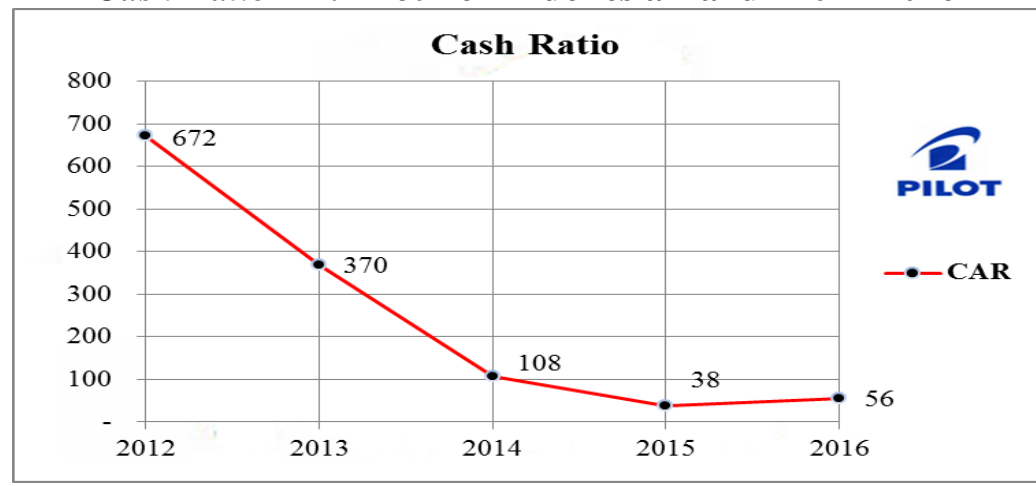

Berdasarkan grafik 4.3. Cash Ratio yang dihasilkan PT. Pilot Pen Indonesia selama tahun 2012-2016 mengalami penurunan setiap tahunnya, dimana besarnya nilai rasio tertinggi terjadi pada tahun 2012 sebesar 672\% dan terendah terjadi pada tahun 2015 sebesar 38\%. Menurunnya nilai Cash Ratio pada tahun 2015 sebesar 38\%, menunjukan semakin kecil kemampuan perusahaan untuk melunasi kewajiban lancarnya yang disebabkan berkurangnya kas perusahaan dan diikuti dengan meningkatnya hutang lancar.

Dengan demikian secara keseluruhan dapat diketahui bahwa selama periode 20122016 diperoleh rata-rata Cash Ratio yang dihasilkan PT. Pilot Pen Indonesia sebesar 249\%. artinya hal ini bisa interprestasikan bahwa untuk satu rupiah kewajiban lancar dapat dijamin dengan 249 rupiah kas perusahaan dalam setahun.

\section{Perhitungan Rasio Solvabilitas}

Rasio Solvabilitas merupakan rasio yang digunakan untuk mengukur sejauh mana aktivitas perusahaan dibiayai dengan hutang.

\section{a. Rasio Utang Terhadap Aktiva (Debt to Assets Ratio)}

Debt to Assets Ratio merupakan rasio perbandingan antara total hutang dengan total aktiva. Rasio ini menunjukan sejauh mana hutang dapat ditutup oleh aktiva. Tabel 4.4 merupakan hasil perhitungan DARatio PT. Pilot Pen Indonesia periode 2012-2016. 
Tabel 4.4

Perhitungan Debt to Assets Ratio PT. Pilot Pen Indonesia

Tahun 2012 - 2016 (dalam rupiah)

\begin{tabular}{|c|c|c|c|}
\hline Tahun & Total Utang & Total Aktiva & DAR \\
\hline 2012 & 8.728 .471 .332 & 101.432 .905 .033 & $0,09 \%$ \\
\hline 2013 & 16.400 .173 .549 & 118.025 .412 .460 & $0,14 \%$ \\
\hline 2014 & 19.974 .985 .022 & 127.223 .906 .356 & $0,16 \%$ \\
\hline 2015 & 24.662 .825 .758 & 128.023 .041 .085 & $0,19 \%$ \\
\hline 2016 & 32.213 .423 .487 & 139.408 .344 .590 & $0,23 \%$ \\
\hline \multicolumn{3}{|c|}{ Rata-Rata Debt to Assets Ratio } & $\mathbf{0 , 1 6 \%}$ \\
\hline
\end{tabular}

Sumber : PT. Pilot Pen Indonesia (diolah)

Apabila digambarkan dalam bentuk grafik, maka nilai Debt to Assets Ratio PT. Pilot Pen Indonesia periode 2012-2016 :

\section{Grafik 4.4}

Debt To Asset Ratio PT. Pilot Pen Indonesia Tahun 2012-2016

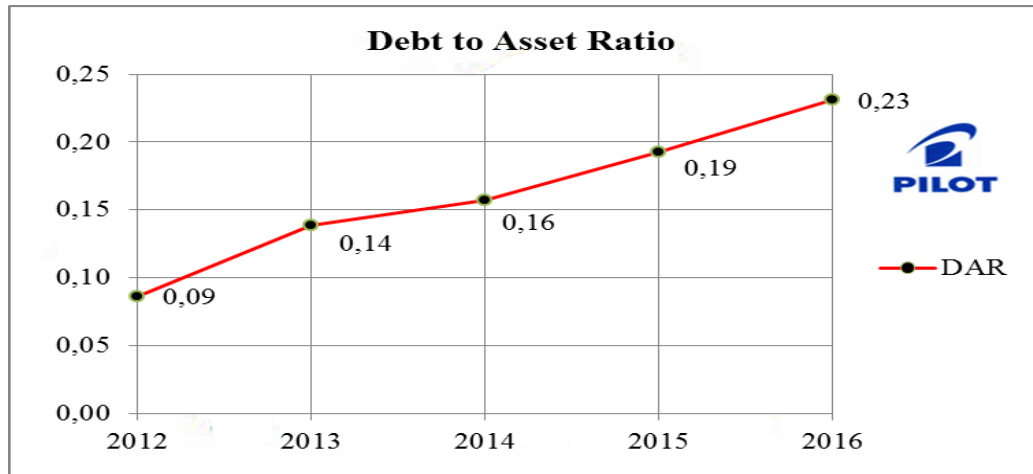

Berdasarkan grafik 4.4. Debt to Assets Ratio yang dihasilkan PT. Pilot Pen Indonesia selama tahun 2012-2016 mengalami peningkatan setiap tahunnya, dimana besarnya nilai rasio tertinggi terjadi pada tahun 2016 sebesar $0,23 \%$ dan terendah terjadi pada tahun 2012 sebesar 0,09\%. Peningkatan nilai Debt to Assets Ratio setiap tahunnya disebabkan adanya peningkatan total utang dibarengi dengan meningkatnya total aktiva.

Dengan demikian secara keseluruhan dapat diketahui bahwa selama periode 20122016 diperoleh rata-rata Debt to Assets Ratio yang dihasilkan PT. Pilot Pen Indonesia sebesar $0,16 \%$. artinya setiap satu rupiah total hutang dapat dijamin oleh total aktiva sebesar Rp0,16.

b. Rasio Utang Terhadap Modal/Ekuitas (Debt to Equity Ratio)

Debt to Equity Ratio merupakan perbandingan antara hutang-hutang dan ekuitas dalam pendanaan perusahaan dan menunjukan kemampuan modal sendiri untuk memenuhi seluruh kewajibanya. Tabel 4.5 merupakan hasil perhitungan Debt to Equity Ratio PT. Pilot Pen Indonesia periode 2012-2016. 
Tabel 4.5. Perhitungan Debt to Equity Ratio PT. Pilot Pen Indonesia Tahun 2012 - 2016 (dalam rupiah)

\begin{tabular}{|c|r|r|r|}
\hline Tahun & Total Utang & Ekuitas & DER \\
\hline 2012 & 8.728 .471 .332 & 92.704 .433 .703 & $0,09 \%$ \\
\hline 2013 & 16.400 .173 .549 & 101.625 .238 .914 & $0,16 \%$ \\
\hline 2014 & 19.974 .985 .022 & 107.247 .921 .336 & $0,19 \%$ \\
\hline 2015 & 24.662 .825 .758 & 103.360 .215 .327 & $0,24 \%$ \\
\hline 2016 & 32.213 .423 .487 & 107.194 .921 .102 & $0,30 \%$ \\
\hline \multicolumn{3}{|c|}{ Rata-Rata Debt to Equity Ratio } & $\mathbf{0 , 2 0 \%}$ \\
\hline
\end{tabular}

Sumber : PT. Pilot Pen Indonesia (diolah)

Apabila digambarkan dalam bentuk grafik, maka nilai Debt to Equity Ratio PT. Pilot Pen Indonesia periode 2012-2016 :

Grafik 4.5

Debt To Equity Ratio PT. Pilot Pen Indonesia Tahun 2012-2016

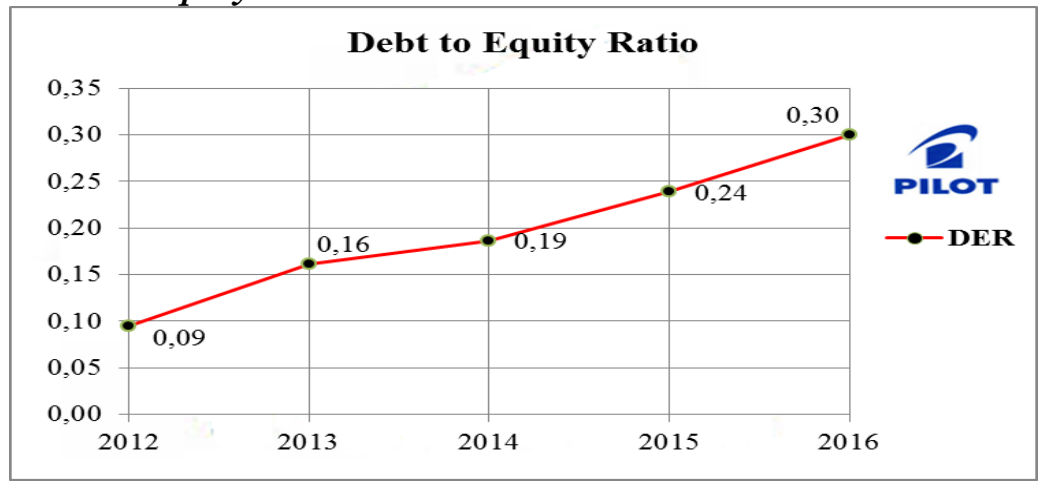

Berdasarkan grafik 4.5 Debt to Equity Ratio yang dihasilkan PT. Pilot Pen Indonesia selama tahun 2012-2016 mengalami peningkatan setiap tahunnya sama halnya yang terjadi pada indikator Debt to Assets Ratio, dimana besarnya nilai rasio tertinggi terjadi pada tahun 2016 sebesar 0,30\% dan terendah terjadi pada tahun 2012 sebesar 0,09\%. Peningkatan nilai Debt to Assets Ratio setiap tahunnya disebabkan adanya peningkatan total utang dibarengi dengan meningkatnya ekuitas.

Dengan demikian secara keseluruhan dapat diketahui bahwa selama periode 20122016 diperoleh rata-rata Debt to Equity Ratio yang dihasilkan PT. Pilot Pen Indonesia sebesar $0,20 \%$. artinya setiap satu rupiah total hutang dapat dijamin oleh modal sendiri sebesar Rp0,20.

\section{Perhitungan Rasio Aktivitas}

Rasio Aktivitas merupakan rasio yang mengukur sejauh mana efektifitas penggunaan aset dengan melihat tingkat aktivitas aset. Dalam penelitian ini penulis hanya menggunakan dua jenis rasio aktivitas, diantaranya :

\section{a. Perputaran Aset Tetap (Fixed Assets Turnover)}

Fixed Assets Turnover merupakan rasio yang digunakan untuk mengukur keefektifan aset tetap yang dimiliki perusahaan dalam menghasilkan penjualan. Tabel 4.6 merupakan hasil perhitungan Fixed Assets Turnover PT. Pilot Pen Indonesia periode 20122016. 
Tabel 4.6

Perhitungan Fixed Assets Turnover PT. Pilot Pen Indonesia Tahun 2012 - 2016 (dalam rupiah)

\begin{tabular}{|c|c|c|c|}
\hline Tahun & Penjualan & $\begin{array}{c}\text { Total } \\
\text { AktivaTetap }\end{array}$ & Rasio \\
\hline 2012 & 88.352 .657 .612 & 21.792 .383 .574 & $4,05 \mathrm{kali}$ \\
\hline 2013 & 97.917 .586 .045 & 22.135 .391 .006 & $4,42 \mathrm{kali}$ \\
\hline 2014 & 99.257 .403 .600 & 23.368 .963 .487 & $4,25 \mathrm{kali}$ \\
\hline 2015 & 114.754 .736 .209 & 74.392 .695 .489 & $1,54 \mathrm{kali}$ \\
\hline 2016 & 124.037 .310 .161 & 105.861 .288 .636 & $1,17 \mathrm{kali}$ \\
\hline \multicolumn{3}{|c|}{ Rata-Rata Fixed Assets Turnover } & $\mathbf{3 , 0 9} \mathrm{kali}$ \\
\hline
\end{tabular}

Sumber : PT. Pilot Pen Indonesia (diolah)

Apabila digambarkan dalam bentuk grafik, maka nilai Fixed Assets Turnover PT. Pilot Pen Indonesia periode 2012- 2016 :

\section{Grafik 4.6}

Fixed Asset Turnover PT. Pilot Pen Indonesia Tahun 2012-2016

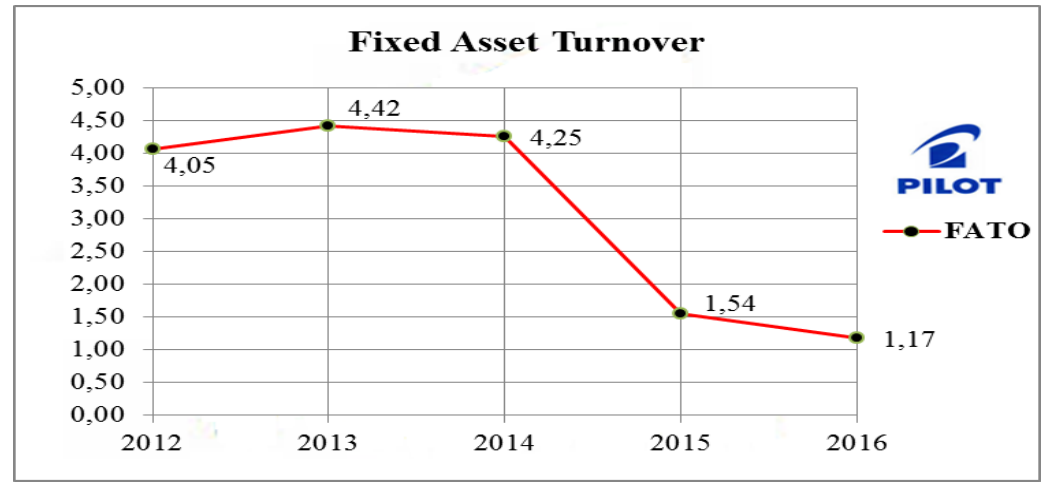

Berdasarkan grafik 4.6 Fixed Assets Turnover yang dihasilkan PT. Pilot Pen Indonesia selama tahun 2012-2016 berfluktuasi, dimana besarnya nilai rasio tertinggi terjadi pada tahun 2013 sebesar 4,42 kali dan terendah terjadi pada tahun 2016 sebesar 1,17 kali. Penurunan cukup signifikan terjadi pada tahun 2016 sebesar 0,37 kali, hal ini terlihat dari tahun 2015 sebesar 1,54 kali menjadi 1,17 kali. Penurunan tersebut disebabkan karena adanya kenaikan penjualan dari Rp114,754,736,209 menjadi Rp124,037,310,161 dan diikuti adanya peningkatan pada aktiva tetap dari Rp74,392,695,489 menjadi Rp105,861,288,636.

Dengan demikian secara keseluruhan diketahui bahwa selama periode 2012-2016 rata-rata Fixed Assets Turnover yang dihasilkan PT. Pilot Pen Indonesia sebesar 3,09 kali artinya setiap satu rupiah aktiva tetap dapat menghasilkan penjualan sebesar Rp3,09.

\section{b. Perputaran Persediaan (Inventory Turnover)}

Inventory Turnover merupakan rasio yang mengukur seberapa efektif perputaran persediaan dengan cara membandingkan antara harga pokok penjualan dengan rata-rata persediaan. Tabel 4.7 merupakan hasil perhitungan Inventory Turnover PT. Pilot Pen Indonesia periode 2012-2016. 
Tabel 4.7. Perhitungan Inventory Turnover PT. Pilot Pen Indonesia

Tahun 2012 - 2016 (dalam rupiah)

\begin{tabular}{|c|c|c|c|}
\hline Tahun & HPP & $\begin{array}{c}\text { Rata-Rata } \\
\text { Persediaan }\end{array}$ & Rasio \\
\hline 2012 & 73.778 .209 .138 & 29.894 .124 .107 & $2,47 \mathrm{kali}$ \\
\hline 2013 & 81.427 .312 .619 & 21.516 .594 .051 & $3,78 \mathrm{kali}$ \\
\hline 2014 & 88.129 .799 .051 & 17.250 .764 .118 & $5,11 \mathrm{kali}$ \\
\hline 2015 & 103.262 .697 .454 & 22.320 .590 .466 & $4,63 \mathrm{kali}$ \\
\hline 2016 & 104.461 .796 .879 & 34.905 .955 .261 & $2.99 \mathrm{kali}$ \\
\hline \multicolumn{3}{|c|}{ Rata-Rata Inventory Turnover } & $\mathbf{3 , 8 0}$ kali \\
\hline
\end{tabular}

Sumber : PT. Pilot Pen Indonesia (diolah)

Apabila digambarkan dalam bentuk grafik, maka nilai Inventory Turnover PT. Pilot Pen Indonesia periode 2012-2016 :

\section{Grafik 4.7}

Inventory Turnover PT. Pilot Pen Indonesia Tahun 2012-2016

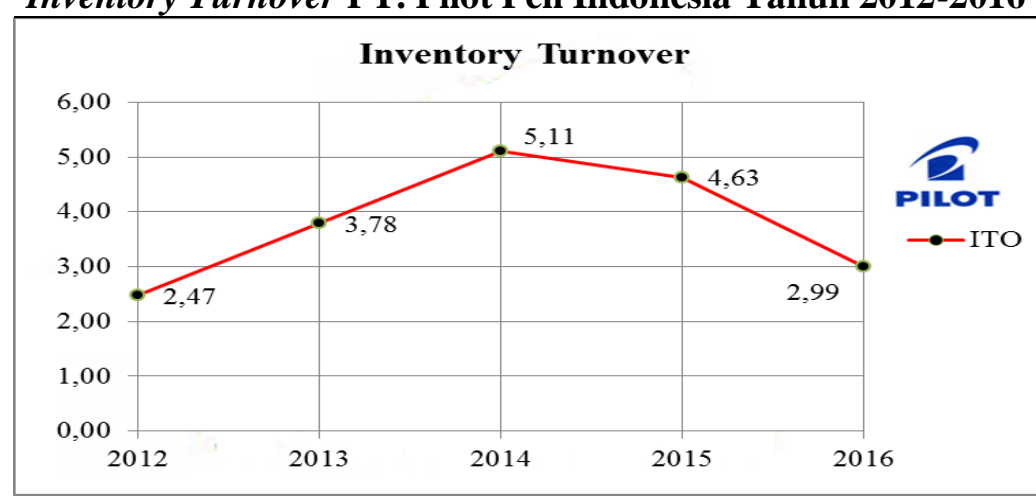

Berdasarkan grafik 4.7 Inventory Turnover yang dihasilkan PT. Pilot Pen Indonesia selama tahun 2012-2016 berfluktuasi, dimana besarnya nilai rasio tertinggi terjadi pada tahun 2014 sebesar 5,11 kali dan terendah terjadi pada tahun 2012 sebesar 2,47 kali.

Dengan demikian secara keseluruhan dapat diketahui bahwa selama periode 20122016 diperoleh rata-rata Inventory Turnover yang dihasilkan PT. Pilot Pen Indonesia sebesar 3,80 kali artinya perputaran persediaan sebesar 3,80 kali menunjukan dana yang tertanam dalam persediaan berputar sebanyak 3,80 dalam setahun.

\section{Perhitungan Rasio Profitabilitas}

Rasio profitabilitas merupakan rasio yang mengukur kemampuan perusahaan dalam menghasilkan profitabilitas pada tingkat penjualan, aset, dan modal saham yang tertentu. Rasio inijuga memberikan gambaran ukuran tingkat efektifitas manajemen suatu perusahaan. Dalam penelitian ini penulis hanya menggunakan tiga jenis rasio profitabilitas, diantaranya :

\section{a. Margin Laba Kotor (Gross Profit Margin)}

Gross Profit Margin merupakan rasio perbandingan antara penjualan bersih dikurangi harga pokok penjualan dengan penjualan bersih dan rasio ini untuk mengukur efektifitas pengendalian harga pokok atau produksinya, yang mengidikasikan kemampuan perusahaan untuk memproduksi secara efesien. Tabel 4.8 merupakan hasil perhitungan Gross Profit Margin PT. Pilot Pen Indonesia periode 2012-2016. 
Tabel 4.8. Perhitungan Gross Profit Margin PT. Pilot Pen Indonesia Tahun 2012 - 2016 (dalam rupiah)

\begin{tabular}{|c|c|c|c|}
\hline Tahun & Penjualan & HPP & $\begin{array}{c}\text { GPM } \\
(\boldsymbol{\%})\end{array}$ \\
\hline 2012 & 88.352 .657 .612 & 73.778 .209 .138 & 16,50 \\
\hline 2013 & 97.917 .586 .045 & 81.427 .312 .619 & 16,84 \\
\hline 2014 & 99.257 .403 .600 & 88.129 .799 .051 & 11,21 \\
\hline 2015 & 114.754 .736 .209 & 103.262 .697 .454 & 10,01 \\
\hline 2016 & 124.037 .310 .161 & 104.461 .796 .879 & 15,78 \\
\hline \multicolumn{3}{|c|}{ Rata-Rata Gross Profit Margin } & $\mathbf{1 4 , 0 7}$ \\
\hline
\end{tabular}

Sumber : PT. Pilot Pen Indonesia (diolah)

Apabila digambarkan dalam bentuk grafik, maka nilai Gross Profit Margin PT. Pilot Pen Indonesia periode 2012-2016 :

Grafik 4.8. Gross Profit Margin PT. Pilot Pen Indonesia Tahun 2012-2016

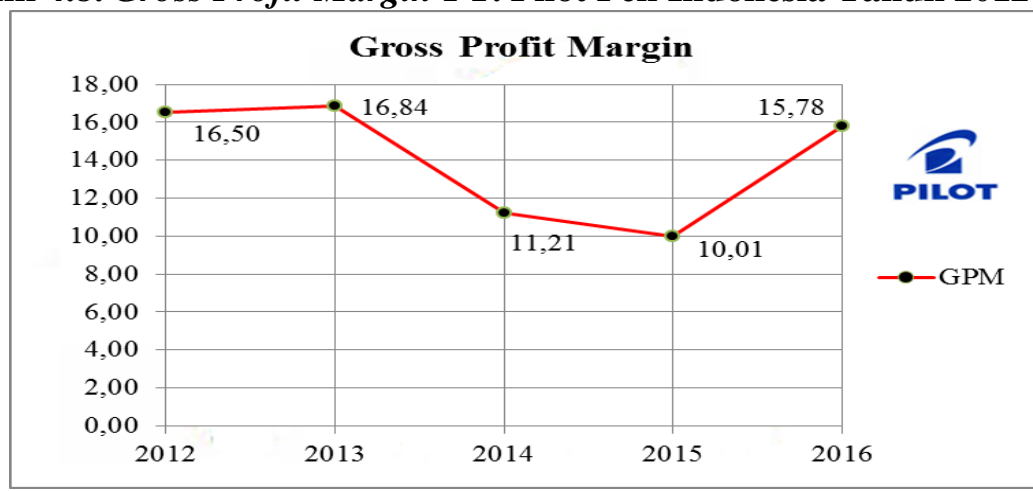

Berdasarkan grafik 4.8 Gross Profit Margin yang dihasilkan PT. Pilot Pen Indonesia selama tahun 2012-2016 berfluktuasi, dimana besarnya nilai rasio tertinggi terjadi pada tahun 2013 sebesar 16,84\% dan terendah terjadi pada tahun 2015 sebesar $10,01 \%$.

Dengan demikian jika dilihat secara keseluruhan dapat diketahui bahwa selama periode 2012-2016 diperoleh rata-rata Gross Profit Margin yang dihasilkan PT. Pilot Pen Indonesia sebesar $14,07 \%$ artinya jumlah laba kotor adalah $14,07 \%$ dari volume penjualan setiap tahunnya.

b. Margin Laba Bersih (Net Profit Margin)

Margin laba bersih merupakan ukuran keuntungan dengan membandingkan antara laba setelah bunga dan pajak dibandingkan dengan penjualan. Pada tabel 4.9 merupakan hasil perhitungan Net Profit Margin PT. Pilot Pen Indonesia Periode 2012-2016.

Tabel 4.9. Perhitungan Net Profit Margin PT. Pilot Pen Indonesia

Tahun 2012 - 2016 (dalam rupiah)

\begin{tabular}{|c|c|c|c|}
\hline Tahun & EAT & Penjualan & $\begin{array}{c}\text { NPM } \\
(\mathbf{\%})\end{array}$ \\
\hline 2012 & 7.565 .258 .178 & 88.352 .657 .612 & 8,56 \\
\hline 2013 & 8.920 .805 .211 & 97.917 .586 .045 & 9,11 \\
\hline 2014 & 5.622 .682 .422 & 99.257 .403 .600 & 5,66 \\
\hline 2015 & -815.705 .390 & 114.754 .736 .209 & $-0,71$ \\
\hline 2016 & 7.017 .652 .621 & 124.037 .310 .161 & 5,66 \\
\hline \multicolumn{3}{|c|}{ Rata-Rata Net Profit Margin } & $\mathbf{5 , 6 6}$ \\
\hline
\end{tabular}

Sumber : PT. Pilot Pen Indonesia (diolah) 
Apabila digambarkan dalam bentuk grafik, maka nilai Net Profit Margin PT. Pilot Pen Indonesia periode 2012-2016 :

\section{Grafik 4.9}

Net Profit Margin PT. Pilot Pen Indonesia Tahun 2012-2016

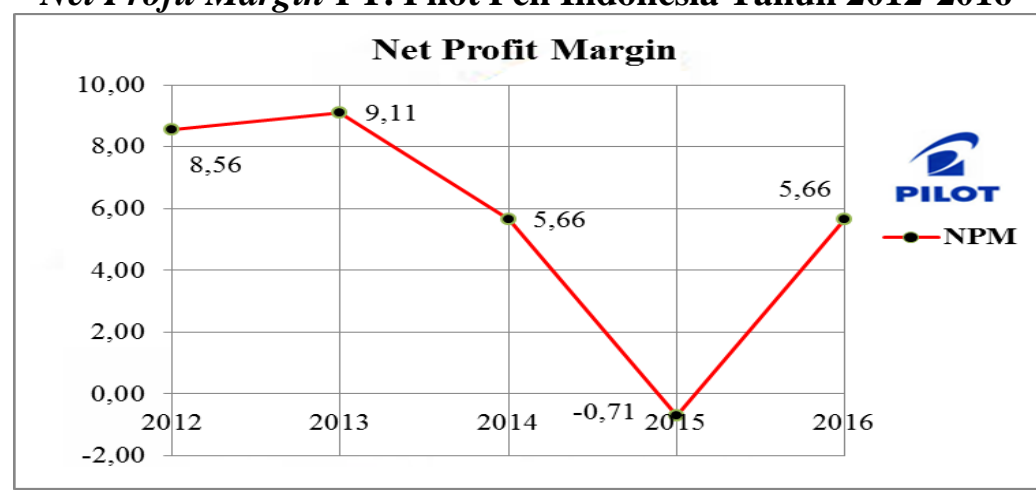

Berdasarkan grafik 4.9 Net Profit Margin yang dihasilkan PT. Pilot Pen Indonesia selama tahun 2012-2016 berfluktiasi setiap tahunnya, dimana besarnya nilai rasio tertinggi terjadi pada tahun 2013 sebesar 9,11\% dan terendah terjadi pada tahun 2015 sebesar 0,71\%. Nilai Net Profit Margin pada tahun 2015 sebesar $-0,71 \%$ disebabkan oleh penurunan laba bersih setelah pajak, hal tersebut telihat pada tahun 2014 sebesar Rp5,622,682,422 menjadi Rp-815,705,390 meskipun terjadi kenaikan penjualan.

Dengan demikian jika dilihat secara keseluruhan dapat diketahui bahwa selama periode 2012-2016 diperoleh rata-rata Net Profit Margin yang dihasilkan PT. Pilot Pen Indonesia sebesar $5,66 \%$ artinya laba bersih yang dihasikan dari total penjualan hanya sekitar 5,66\% setiap tahunnya.

\section{c. Hasil Pengembalian Modal Sendiri (Return on Equity)}

Return on Equity merupakan rasio atau rentabilitas modal sendiri merupakan rasio untuk mengukur laba bersih sesudah pajak dengan modal sendiri. Rasio ini menunjukkan efisiensi penggunaan modal sendiri. Pada tabel 4.10 merupakan hasil perhitungan return on equity PT. Pilot Pen Indonesia Periode 2012-2016.

\section{Tabel 4.10}

Perhitungan Return on Equity PT. Pilot Pen Indonesia Tahun 2012 - 2016 (dalam rupiah)

\begin{tabular}{|c|r|r|c|}
\hline Tahun & EAT & Equity & ROE (\%) \\
\hline 2012 & 7.565 .258 .178 & 92.704 .433 .703 & 8,16 \\
\hline 2013 & 8.920 .805 .211 & 101.625 .238 .914 & 8,78 \\
\hline 2014 & 5.622 .682 .422 & 107.247 .921 .336 & 5,24 \\
\hline 2015 & -815.705 .390 & 103.360 .215 .327 & $-0,79$ \\
\hline 2016 & 7.017 .652 .621 & 107.194 .921 .102 & 6,55 \\
\hline \multicolumn{3}{|c|}{ Rata-Rata Return on Equity } & $\mathbf{5 , 5 9}$ \\
\hline
\end{tabular}

Sumber : PT. Pilot Pen Indonesia (diolah)

Apabila digambarkan dalam bentuk grafik, maka nilai Return on Equity PT. Pilot Pen Indonesia periode 2012-2016 : 
Grafik 4.10

Return on Equity PT. Pilot Pen Indonesia Tahun 2012-2016

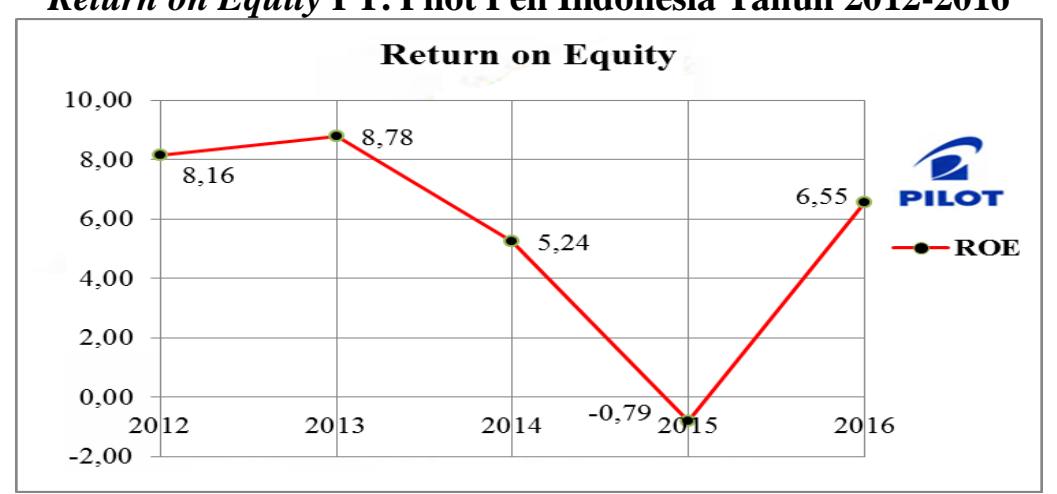

Berdasarkan grafik 4.10 Return on Equity yang dihasilkan PT. Pilot Pen Indonesia selama tahun 2012-2016 berfluktiasi setiap tahunnya, dimana besarnya nilai rasio tertinggi terjadi pada tahun 2013 sebesar 8,78\% dan terendah terjadi pada tahun 2015 sebesar 0,79\%. Nilai Return on Equity pada tahun 2015 sebesar -0,79\% disebabkan penurunan laba bersih setelah bunga dan pajak, hal tersebut telihat pada tahun 2014 sebesar Rp5,622,682,422 menjadi Rp-815,705,390 meskipun hal tersebut terjadi kenaikan penjualan.

Dengan demikian jika dilihat secara keseluruhan dapat diketahui bahwa selama periode 2012-2016 diperoleh rata-rata Return on Equity yang dihasilkan PT. Pilot Pen Indonesia sebesar 5,59\% artinya laba bersih yang mampu dihasilkan dengan memanfaatkan modal dari pemilik perusahaan hanya sekitar 5,59\%.

\section{Penilaian Kinerja Keuangan Perusahaan}

Penilaian kinerja merupakan suatu proses untuk menyediakan infomasi tentang sejauh mana suatu kegiatan tertentu telah tercapai. Analisis rasio keuangan digunakan untuk pengevaluasian aspek-aspek keuangan meliputi tingkat likuiditas, solvabilitas, aktivitas dan profitabilitas. Dengan membandingkan rasio keuangan pada beberapa tahun penilaian, dapat dilihat bagaimana kemajuan ataupun kemunduran kinerja. Apabila hasil analisis rasio keuangan perusahaan lebih besar atau di atas rasio industri, maka kondisi keuangan perusahaan dikatakan efesien (baik) dan apabila perhitungan rasio keuangan perusahaan lebih kecil atau dibawah standar, maka kondisi keuangan perusahaan tidak efesien (tidak baik). 
TABEL 4. 11

PENILAIAN KINERJA KEUANGAN PT. PILOT PEN INDONESIA

TAHUN 2012 s.d 2016

\begin{tabular}{|c|c|c|c|c|c|c|c|c|}
\hline \multirow{2}{*}{ Keterangan } & \multicolumn{5}{|c|}{ Tahun } & $\begin{array}{c}\text { Rata-Rata } \\
\text { Industri }\end{array}$ & $\begin{array}{c}\text { Standar } \\
\text { Industri }\end{array}$ & \multirow{2}{*}{ Kondisi } \\
\cline { 2 - 9 } & $\mathbf{2 0 1 2}$ & $\mathbf{2 0 1 3}$ & $\mathbf{2 0 1 4}$ & $\mathbf{2 0 1 5}$ & $\mathbf{2 0 1 6}$ & & & \\
\hline Likuiditas & & & & & & & & \\
\hline CR (kali) & 10,48 & 5,34 & 2,52 & 2,02 & 2,10 & 4,49 & 2 kali & Likuid \\
\hline QR (kali) & 7,99 & 4,46 & 1,95 & 0,99 & 1,24 & 3,33 & 1,5 kali & Likuid \\
\hline CAR (\%) & 672 & 370 & 108 & 38 & 56 & 249 & $50 \%$ & Likuid \\
\hline Solvabilitas & & & & & & & & \\
\hline DAR (\%) & 0,09 & 0,14 & 0,16 & 0,19 & 0,23 & 0,16 & $35 \%$ & Solvabel \\
\hline DER (\%) & 0,09 & 0,16 & 0,19 & 0,24 & 0,30 & 0,20 & $90 \%$ & Solvabel \\
\hline Aktivitas & & & & & & & & \\
\hline FATO (kali) & 4,05 & 4,42 & 4,25 & 1,54 & 1,17 & 3,09 & 5 kali & Tidak Efesien \\
\hline ITO (kali) & 2,47 & 3,78 & 5,11 & 4,63 & 2,29 & 3,80 & 20 kali & Tidak Efesien \\
\hline Profitabilitas & & & & & & & & \\
\hline GPM (\%) & 16,50 & 16,84 & 11,21 & 10,01 & 15,78 & 14,07 & $30 \%$ & Tidak Efesien \\
\hline NPM (\%) & 8,56 & 9,11 & 5,66 & $-0,71$ & 5,66 & 5,66 & $20 \%$ & Tidak Efesien \\
\hline ROE (\%) & 8,16 & 8,78 & 5,24 & $-0,79$ & 6,55 & 5,59 & $40 \%$ & Tidak Efesien \\
\hline SO
\end{tabular}

Sumber PT. Pilot Pen Indonesia 2012-2016 (diolah)

Dari tabel 4.11 dapat terlihat rata-rata rasio keuangan yang dihasilkan PT. Pilot Pen Indonesia, maka interprestasi kondisi keuangan sebagai berikut :

a. Kinerja Keuangan ditinjau dari Likuiditas

1). Rasio Lancar (Current Ratio)

Current Ratio menunjukan berapa kali aset lancar dapat membiayai kewajiban lancar perusahaan. Semakin tinggi rasio ini maka semakin baik kinerja keuangan perusahaan. Menurut Kasmir (2012:143) standar industri Current Ratio adalah sebesar 2 kali. Berdasarkan hasil perhitungan secara keseluruhan Current Ratio yang dihasilkan PT. Pilot Pen Indonesia selama 5 tahun sebesar 4,49 kali, dimana hasil ini menunjukan likuiditas perusahaan untuk memenuhi kewajiban jangka pendeknya dikategorikan "cukup baik" (likuid), Tetapi Current Ratio yang terlalu tinggi akan berdampak pada menurunnya tingkat profitabilitas (kemampuan perusahaan dalam menghasilkan laba), hal ini disebabkan masih banyaknya aktiva/modal yang menganggur.

2). Rasio Cepat (Quick Ratio)

Quick Ratio menunjukan berapa kali aset lancar dalam memenuhi atau membayar kewajiban atau utang lancar (utang jangka pendek) dengan aktiva lancar tanpa memperhatikan nilai persediaan (inventory). Semakin tinggi nilai rasio ini maka menunjukan semakin baik kinerja keuangan yang dicapai perusahaan. Standar rasio yang dikemukakan Kasmir (2012:143) adalah sebanyak 1,5 kali.

Berdasarkan hasil perhitungan Quick Ratio secara keseluruhan yang dihasilkan PT. Pilot Pen Indonesia selama 5 tahun sebesar 3,33 kali, dimana hasil ini menunjukan likuiditas perusahaan untuk memenuhi kewajiban jangka pendeknya dikategorikan "cukup baik" (likuid). Akan tetapi, Quick Ratio yang terjadi pada tahun 2015 dikategorikan tidak baik, hal ini akan semakin sulit perusahaan memenuhi kewajiban jangka pendeknya. Penurunan nilai Quick Ratio tersebut disebabkan adanya kenaikan kewajiban lancar dari Rp19,030,822,852 menjadi Rp22,478,479,256 dan diikuti dengan adanya kenaikan persediaan dari Rp10,827,299,727 menjadi Rp22,986,581,478, sedangkan pada aktiva 
lancar penurunan dari sebesar Rp47,903,238,539 menjadi Rp45,321,745,926 dan penurunan dari sisi kas dan setara kas dibanding tahun 2014.

\section{3). Rasio Kas (Cash Ratio)}

Cash Ratio merupakan rasio yang digunakan untuk mengukur kemampuan perusahaan dalam membayar kewajiban jangka pendek dengan kas yang tersedia di bank. Semakin tinggi nilai rasio ini maka semakin baik kinerja keuangan yang yang dilakukan perusahaan. Standar rasio yang dikemukakan Kasmir (2013:137) sebesar 50\%.

Berdasarkan hasil perhitungan Cash Ratio pada secara keseluruhan yang dihasilkan PT. Pilot Pen Indonesia selama 5 tahun sebesar 249\%, dimana hasil ini menunjukan likuiditas perusahaan untuk memenuhi kewajiban jangka pendeknya dikategorikan "cukup baik" (likuid). Akan tetapi, Cash Ratio pada tahun 2015 mengalami penurunan sebesar 69,53\%, hal ini terlihat dari tahun 2014 sebesar 107,52\% menjadi 38\%. Penurunan ini disebabkan karena menurunnya pada jumlah kas yang dimiliki perusahaan dan kenaikan pada kewajiban lancar yang tidak sesuai sehingga perusahaan tidak likuid sehingga akan kesulitan perusahaan untuk memenuhi kewajiban jangka pendeknya sementara kas dan setara kas lebih kecil dibandingkan dengan kewajiban lancarnya.

b. Kinerja Keuangan ditinjau dari solvabilitas

1). Rasio Utang Terhadap Aktiva (Debt to Asset Ratio)

Debt to Asset Ratio menunjukan sejauh mana hutang dapat ditutupi oleh aktiva. Semakin rendah nilai rasio ini menunjukan bahwa semakin baik keadaan keuangan perusahaan. Standar industri untuk rasio ini menurut Kasmir (2014:156) sebesar 35\%.

Berdasarkan hasil perhitungan Debt to Asset Ratio secara keseluruhan yang dihasilkan PT. Pilot Pen Indonesia selama 5 tahun sebesar $0,16 \%$ berada di atas standar industri (35\%). Hal ini menunjukan bahwa kinerja keuangan dalam kategori "baik (solvable)" karena perusahaan mampu menutupi total hutang dengan total aset yang dimiliki, dimana perusahaan memiliki total aset jauh lebih besar dari total hutang. Sedangkan jika dilihat setiap tahunnya nilai Debt to Asset Ratio dalam kategori solvable.

2). Rasio Utang Terhadap Modal (Debt to Equity Ratio)

Debt to Equity Ratio merupakan rasio yang membandingkan utang perusahaan dengan total ekuitas. Rasio ini mengukur presentase dana yang disediakan oleh kreditur, kewajiban meliputi hutang jangka pendek dan semua hutang jangka panjang dan setiap rupiah modal sendiri dijadikan untuk jaminan utang. Semakin tinggi nilai rasio ini menunjukan bahwa kinerja keuangan perusahaan buruk, maka perusahaan harus berusaha agar Debt to Equity Ratio rendah atau berada di bawah standar industri. Standar industri untuk rasio ini menurut Kasmir (2014:164) sebesar 90\%.

Berdasarkan hasil perhitungan Debt to Equity Ratio secara keseluruhan yang dihasilkan PT. Pilot Pen Indonesia selama 5 tahun sebesar 0,20\%. Hasil analisa rasio menunjukan bahwa rata-rata Debt to Equity Asset Ratio PT. Pilot Pen Indonesia selang lima tahun terakhir berada di atas standar industri (90\%). Indikasi ini memperlihatkan bahwa rata-rata kinerja PT. Pilot Pen Indonesia tergolong "baik (solvable)", artinya total saham yang dimiliki perusahaan melebihi total hutang perusahaan. Sedangkan jika dilihat setiap tahunnya nilai Debt to Equity Ratio dalam kategori "baik (solvable)".

c. Kinerja Keuangan ditinjau dari aktivitas

1). Perputaran Aset Tetap (Fixed Asset Turnover)

Fixed Asset Turnover merupakan rasio yang membandingkan penjualan dengan total aktiva tetap. Rasio ini untuk mengukur apakah perusahan sudah menggunakan kapasitas aktiva tetap dengan sepenuhnya atau belum. Semakin tinggi nilai rasio ini menunjukan bahwa efesien modal kerja yang ditanamkan dalam persediaan. Standar industri untuk rasio ini menurut Kasmir (2014:180) sebesar 5 kali perputaran aktiva tetap.

Berdasarkan hasil perhitungan Fixed Asset Turnover secara keseluruhan Fixed Asset Turnover yang dihasilkan PT. Pilot Pen Indonesia selama 5 tahun sebesar 3,09 kali. 
Hasil analisa rasio ini menunjukan bahwa rata-rata Fixed Asset Turnover PT. Pilot Pen Indonesia selang lima tahun terakhir berada di bawah standar industri (5 kali). Indikasi ini memperlihatkan bahwa rata-rata kinerja PT. Pilot Pen Indonesia tergolong "tidak baik (tidak efesien)", karena perusahaan memiliki aset tetap yang ada belum sepenuhnya dimanfaatkan secara maksimal dalam menciptakan penjualan dalam setahunnya. Sedangkan jika dilihat setiap tahunnya nilai Fixed Asset Turnover pada tahun 2012 sampai 2014 hampir mendekati di atas standar rasio industri masing-masing sebesar 4,05 kali, 4,42 kali dan 4,25 kali. Namun demikian, pada tahun 2015 dan 2016 masing-masing diperoleh sebesar 1,54 kali dan 1,17 kali. Hal ini dikarenakan meskipun pada tahun 2015 dan 2016 terjadi peningkatan aktiva tetap, namun tidak dimanfaatkan secara maksimal dalam menciptakan penjualan.

2). Perputaran Persediaan (Inventory Turnover)

Inventory Turnover adalah rasio antara harga pokok penjualan terhadap persediaan rata-rata menunjukan seberapa cepat persediaan tersebut dapat dijual. Semakin tinggi nilai rasio ini, maka semakin baik dan efesien modal kerja yang ditanamkan dalam persediaan. Standar industri untuk rasio ini menurut Kasmir (2014:180) sebesar 20 kali perputaran persediaan.

Berdasarkan hasil perhitungan Inventory Turnover secara keseluruhan yang dihasilkan PT. Pilot Pen Indonesia selama 5 tahun sebesar 3,80 kali. Hasil analisa rasio ini menunjukan bahwa rata-rata Inventory Turnover PT. Pilot Pen Indonesia selang lima tahun terakhir berada di bawah standar industri (20 kali). Indikasi ini memperlihatkan bahwa rata-rata kinerja PT. Pilot Pen Indonesia tergolong "tidak baik (tidak efesien) apabila dibandingkan dengan standar rasio industri. Hal tersebut disebabkan masih banyaknya persediaan barang dagangan yang menumpuk di gudang dan lambatnya penjualan persediaan. Sedangkan jika dilihat setiap tahunnya nilai Inventori Turnover adalah selalu di bawah rata-rata industri.

d. Kinerja Keuangan ditinjau dari profitabilitas

1). Margin Laba Kotor (Gross Profit Margin)

Gross Profit Margin adalah rasio yang dapat menunjukan laba yang relatif terhadap perusahaan, dan rasio ini pun merupakan cara untuk menetapkan harga pokok penjualan. Semakin tinggi nilai rasio ini, maka semakin baik keadaan operasi perusahaan, hal ini menunjukan bahwa harga pokok penjualan relatif lebih rendah dibandingkan. Standar industri untuk rasio ini menurut Kasmir (2014:196) sebesar 30\%.

Berdasarkan hasil perhitungan Gross Profit Margin secara keseluruhan yang dihasilkan PT. Pilot Pen Indonesia selama 5 tahun cukup berfluktuatif. Pertumbuhan tertinggi terjadi pada tahun 2013, yakni $16,84 \%$, sementara terendah terjadi pada tahun 2015, yakni sebesar 10,01\%. Dengan demikian, kinerja keuangan PT. Pilot Pen Indonesia dikategorikan "kurang baik" bagi operasi perusahaan dan masih berada di bawah rata-rata industri setiap tahunnya. Sedangkan untuk rata-rata nilai Gross Profit Margin yang dihasilkan PT. Pilot Pen Indonesia selama 2012-2016 diperoleh sebesar 14,07\%. Dari hasil ratio Gross Profit Margin baik tiap tahun maupun rata-rata selama lima tahun dikategorikan "kurang baik" karena masih jauh dari rata-rata industri. Hal ini berarti perusahaan masih tidak bisa mengandalikan biaya persediaan atau biaya operasi barang maupun untuk meneruskan kenaikan harga lewat penjualan kepada pelangggan.

2). Margin Laba Bersih (Net Profit Margin)

Net Profit Margin adalah keuntungan penjualan setelah menghitung biaya dan pajak penghasilan. Semakin tinggi nilai rasio ini maka akan menunjukan semakin baik kinerja keuangan yang dicapai perusahaan. Standar industri untuk rasio ini menurut Kasmir (2012:136) sebesar 20\%.

Berdasarkan hasil perhitungan Net Profit Margin secara keseluruhan yang dihasilkan PT. Pilot Pen Indonesia selama 5 tahun berada jauh di bawah rata-rata industri yang berarti kinerja keuangan perusahaan dalam kategori "tidak baik" setiap tahunnya. 
Sedangkan rata-rata nilai Net Profit Margin yang dihasilkan PT. Pilot Pen Indonesia selama 2012-2016 diperoleh sebesar 5,66\%. Dimana dari hasil rata-rata tersebut menunjukan bahwa kinerja perusahaan untuk menghasilkan laba bersih dari penjualan bersihnya kurang baik karena meskipun total penjualan meningkat setiap tahunnya, tetapi laba bersih yang dihasilkan dari total penjualan hanya sekitar 5,66\%. Indikasi ini memperlihatkan bahwa harga barang-barang perusahaan relatif tinggi, hal ini kemungkinan meningkatnya biaya tidak langsung terhadap penjualan atau karena beban pajak yang tinggi.

3). Hasil Pengembalian Modal Sendiri (Return on Equity)

Return on Equity merupakan suatu pengukuran dan penghasilan yang tersedia bagi para pemihak maupun perusahaan atas modal yang diinvestasikan dalam perusahaan. Semakin tinggi nilai rasio ini maka akan menunjukan semakin baik kinerja keuangan yang dicapai perusahaan. Standar industri untuk rasio ini menurut Kasmir (2014:196) sebesar $40 \%$.

Berdasarkan hasil perhitungan Return on Equity secara keseluruhan yang dihasilkan PT. Pilot Pen Indonesia selama 5 tahun berada jauh di bawah rata-rata industri yang berarti kinerja keuangan perusahaan dalam kategori "tidak baik" setiap tahunnya. Sedangkan untuk rata-rata nilai Return on Equity yang dihasilkan PT. Pilot Pen Indonesia selama 2012-2016 diperoleh sebesar 5,59\%. Dimana dari hasil rata-rata tersebut menunjukan bahwa kinerja perusahaan untuk menghasilkan laba bersih dengan memanfaatkan seluruh modal sendiri dari pemilik perusahaan adalah "kurang baik", karena laba bersih yang mampu dihasilkan dengan memanfaatkan modal dari pemilik perusahaan hanya sekitar 5,59\% setiap tahunnya. Meskipun nilai ini masih jauh dari rata-rata industri, pengembalian modal sedikit lebih baik dari tahun ke tahun.

\section{PENUTUP}

Berdasarkan hasil analisa yang telah dilakukan terhadap laporan keuangan PT. Pilot Pen Indonesia selama kurun waktu lima periode akuntansi yaitu dari tahun 2012 s.d. 2016 dengan menggunakan analisis rasio likuiditas, solvabilitas, aktivitas dan profitabilitas dapat diambil kesimpulan sebagai berikut:

a. Hasil analisis rasio likuiditas PT. Pilot Pen Indonesia.

Secara keseluruhan rata-rata Current Ratio yang dihasilkan PT. Pilot Pen Indonesia selama 5 tahun sebesar 4,49 kali, dimana hasil ini menunjukan likuiditas perusahaan untuk memenuhi kewajiban jangka pendek dengan dengan aktiva lancar dikategorikan cukup baik (likuid) di atas standar rasio industri sebesar 2 kali. Namun demikian, pencapaian Current Ratio terlalu tinggi akan mengakibatkan menurunnya tingkat profitabilitas (kemampuan perusahaan dalam menghasilkan laba) karena masih banyaknya aktiva/dana perusahaan yang menganggur.

Rasio Cepat (Quick Ratio) yang dihasilkan PT. Pilot Pen Indonesia selama 5 tahun sebesar 3,33 kali, dimana hasil ini menunjukan likuiditas perusahaan untuk memenuhi kewajiban jangka pendeknya dengan aktiva lancar dikategorikan "cukup baik" (likuid). Akan tetapi, Quick Ratio pada tahun 2015 dikategorikan tidak baik, karena hal ini akan semakin sulit perusahaan memenuhi kewajiban jangka pendeknya dengan aktiva lancar. Penurunan nilai Quick Ratio yang terjadi pada tahun 2015 disebabkan, adanya kenaikan kewajiban lancar dan persediaan serta adanya penurunan dari sisi kas dan setara kas dibanding tahun 2014. Hal ini mengakibatkan menurunnya tingkat profitabilitas (kemampuan perusahaan dalam menghasilkan laba) karena masih banyaknya aktiva/dana perusahaan yang menganggur.

Sedangkan Rasio Kas (Cash Ratio) yang dihasilkan PT. Pilot Pen Indonesia selama 5 tahun secara keseluruhan sebesar $249 \%$, dimana hasil ini menunjukan likuiditas perusahaan untuk memenuhi kewajiban jangka pendeknya dengan kas dan setara kas dikategorikan "cukup baik" (likuid). Akan tetapi, Cash Ratio pada tahun 2015 mengalami penurunan sebesar 69,53\%, yang disebabkan penurunan pada jumlah kas yang dimiliki perusahaan dan kenaikan pada 
kewajiban lancar sehingga perusahaan akan kesulitan untuk memenuhi kewajiban jangka pendeknya dimana kas dan setara kas lebih kecil dibandingkan dengan kewajiban lancarnya.

b. Hasil analisis rasio solvabilitas PT. Pilot Pen Indonesia

Secara keseluruhan Debt to Asset Ratio yang dihasilkan PT. Pilot Pen Indonesia selama 5 tahun sebesar $0,16 \%$, dimana hasil ini menunjukan kemampuan perusahaan menutupi total hutang dengan total aset dalam kategori "baik (solvable)" karena total aset yang dimiliki perusahaan jauh lebih besar dari total hutang.

Sedangkan berdasarkan indikator Debt to Equity Ratio yang dihasilkan PT. Pilot Pen Indonesia secara keseluruhan sebesar 0,20\%, dimana hasil ini menunjukan kinerja keuangan perusahaan dikategorikan "cukup baik (solvable)", karena total saham/modal sendiri yang dimiliki perusahaan lebih besar dari total hutang.

c. Hasil analisis rasio aktivitas PT. Pilot Pen Indonesia

Fixed Asset Turnover secara keseluruhan yang dihasilkan PT. Pilot Pen Indonesia selama 5 tahun sebesar 3,09 kali, Indikasi ini memperlihatkan bahwa rata-rata kinerja PT. Pilot Pen Indonesia tergolong "tidak baik (tidak efesien)", dimana hasil ini menunjukan efektifitas perusahaan dalam menciptakan penjualan belum maksimal meskipun tingkat penjualan setiap tahunnya mengalami peningkatan. Sedangkan jika dilihat setiap tahunnya nilai Fixed Asset Turnover pada tahun 2012 sampai 2014 hampir mendekati di atas standar rasio industri masingmasing sebesar 4,05 kali, 4,42 kali dan 4,25 kali.

Sedangkan Perputaran Persediaan (Inventory Turnover) yang dihasilkan PT. Pilot Pen Indonesia selama 5 tahun rata-rata sebesar 3,80 kali. Indikasi ini memperlihatkan bahwa ratarata kinerja PT. Pilot Pen Indonesia tergolong "tidak baik (tidak efesien)", karena banyak persediaan barang dagangan yang menumpuk di gudang sehingga akan mengakibatkan tingkat pengembalian investasi yang rendah.

d. Hasil analisis rasio profitabilitas PT. Pilot Pen Indonesia

Gross Profit Margin yang dihasilkan PT. Pilot Pen Indonesia selama 5 tahun secara keseluruhan sebesar 14,07\% dikategorikan "kurang baik" karena masih jauh dari rata-rata industri. Hal ini disebabkan perusahaan belum memaksimalkan pengendalian biaya persediaan atau biaya operasi barang maupun untuk meneruskan kenaikan harga lewat penjualan kepada pelangggan.

Margin Laba Bersih (Net Profit Margin) diperoleh rata-rata 5,66\%. Dimana dari hasil rata-rata tersebut menunjukan bahwa kinerja perusahaan untuk menghasilkan laba bersih dari penjualan bersihnya "kurang baik". Indikasi ini memperlihatkan bahwa harga barang-barang perusahaan relatif tinggi dan meningkatnya biaya tidak langsung terhadap penjualan atau karena beban pajak yang tinggi.

Sedangkan Return on Equity secara keseluruhan sebesar 5,59\% dikategorikan kinerja perusahaan untuk menghasilkan laba bersih dengan memanfaatkan seluruh modal sendiri dari pemilik perusahaan adalah "kurang baik". Namun demikian, untuk pengembalian modal sedikit lebih baik dari tahun ke tahun.

Berdasarkan hasil penelitian dan simpulan yang telah dikemukakan, maka peneliti dapat memberikan saran-saran yang berkaitan dengan penelitian ini sebagai berikut:

a. Dilihat dari aspek rasio likuiditas (current ratio, quick ratio dan cash ratio) Besaran rasio ini menunjukan cukup baik (likuid) dalam menggunakan aktiva lancarnya, hal ini perlu dipertahankan agar supaya keadaan perusahaan terus dikatakan lancar dalam memenuhi kewajiban jangka pendeknya, memaksimalkan pengendalian terhadap persediaan barang dagangnya, mempertahankan kas (yang berasal dari volume penjualan) dan memperhatikan kondisi piutang, serta memaksimalkan aktiva perusahaan untuk kegiatan operasi.

b. Ditinjau dari aspek rasio solvabilitas (debt to asset ratio, debt to equity ratio) Kondisi perusahaan ini di atas rata-rata industri. Dimana dalam memanfaatkan aktiva perusahaan cukup baik, hal ini akan mempermudah perusahaan untuk memperoleh pinjaman. Hasil 
perolehan likuiditas ini perlu dipertahankan, sedangkan untuk memaksimalkan perolehan laba perusahaan memaksimalkan modal secara efesien untuk kegiatan opersional perusahaan.

c. Ditinjau dari aspek rasio aktivitas (fixed asset turnover, inventory turnover) menunjukan bahwa dana yang tertanam dalam mengasilkan penjualan kurang efesien. Oleh sebab itu, perusahaan mempertimbangkan untuk memaksimalkan dan meningkatkan volume penjualan dari persediaan dengan memanfaatkan aktiva-aktiva yang dimiliki perusahaan maupun memanfaatkan modal sendiri agar laba yang diperoleh lebih optimal.

d. Ditinjau dari aspek profitabilitas (gross profit margin, net profit margin dan return on equity) menunjukan rasio profuitabilitas perusahaan kurang baik (tidak efesien). oleh karena itu, perusahaan mempertimbangkan untuk memaksimalkan penjulan dengan memanfaatkan modal sendiri yang dimiliki secara efektif dan juga menggunakan aktiva secara efesien dan meminimalisir/menekan biaya-biaya yang terjadi agar dapat meningkatkan laba usaha.

e. Bagi peneliti selanjutnya diharapkan agar dapat membuat analisis kinerja keuangan perusahaan dengan sampel perusahaan yang lebih banyak sehingga dapat diketahui trend perbandingan dengan kinerja perusahaan lainnya dan diharapkan melakukan pengukuran atau penilaiaan kinerja keuangan perusahaan dalam aspek operasional dan aspek administrasi tidak hanya aspek keuangannya saja.

\section{REFERENSI}

Yunirahmayanti, Andiana et.al., (2016). Analisis Laporan Keuangan (Kinerja Keuangan) untuk Memberikan Dasar Pengambilan Keputusan Investasi Saham pada Perusahaan Sub Sektor Pulp \& Paper yang terdaftar di BEI. Universitas Pakuan Bogor.

Sugiono, Arief dan Untung, Edi (2016). Panduan Praktis Dasar Analisis Laporan Keuangan. Jakarta: Grasindo

Hermanto, Bambang, Mulyo Agung (2015). Analisa Laporan Keuangan, Cetakan ke-1, Lentera Ilmu Cendekia.

Dessie Handayani, et.al., (2013). Analisis Kinerja Keuangan Berdasarkan Rasio Profitabilitas pada PT. Bhimex di Samarinda. Fakultas Ekonomi Universitas Mulawarman

Fahmi, Irham. (2014) Analisis Laporan Keuangan. Bandung: Alfabeta.

Harahap, Sofyan Syafri, 2015, Analisis Kritis Atas Laporan Keuangan, Cetakan Kedua Belas, Raja Grafindo Persada, Jakarta

Hery. 2015. Analisis Laporan Keuangan Pendekatan Rasio Keuangan. Yogyakarta : Center for Academic Publising Service.

Hery. (2015). Analisis Kinerja Manajemen The Best Financial Analysis. Jakarta: PT Grasindo.

Ikatan Akuntansi Indonesia. 2015. Pernyataan Standar Akuntansi Keuangan (PSAK) No 1 Penyajian Laporan Keuangan, Jakarta.

Kasmir. 2014. Analisis Laporan Keuangan. Jakarta : PT Raja Grafindo Persada

Munawir, S. 2012. Analisis Informasi Keuangan, Liberty, Yogyakarta.

Rahmah, Mutiara Nur dan Komariah, Euis (2016). Analisis Laporan Keuangan Dalam Menilai Kinerja Keuangan Industri Semen Yang Terdaftar Di BEI. Jurnal Online Insan Akuntan, Vol.1, No.1, Juni 2016, 43 - 58. E-ISSN: 2528-0163

Fajrin, Putri Hidayatul dan Laily, Nur (2016). Analisis Profitabilitas dan Likuiditas Terhadap Kinerja Keuangan Pt. Indofood Sukses Makmur, Tbk. Jurnal Ilmu dan Riset Manajemen : Vol. 5, No. 6, Juni 2016 (ISSN : 2461-0593)

Rhamadana, Recly Bima (2016). Analisis Rasio Keuangan untuk Menilai Kinerja Keuangan PT. H.M Sampoerna Tbk. Jurnal Ilmu dan Riset Manajemen, Vol. 5, No. 7, Juli 2016, ISSN : 2461-0593.

Rudianto. 2013. Akuntansi Manajemen Informasi untuk Pengambilan Keputusan Strategis. Jakarta: Erlangga.

Sjahrial, Dermawan dan Djahotman Purba. 2013. Analisis Laporan Keuangan. Jakarta: Mitra Wacana Media. 